\title{
Clinical Importance of Sound-Field Speech Recognition Test for Measurement of Hearing Aid Benefit
}

\author{
Yoseb Ko ${ }^{1,2}$ and Jae Hee Lee ${ }^{1,3}(\mathbb{C})$ \\ ${ }^{1}$ Department of Audiology and Speech-Language Pathology, Hallym University of Graduate Studies, Seoul; and \\ ${ }^{2}$ St. Carollo General Hospital, Suncheon; and ${ }^{3}$ HUGS Center for Hearing and Speech Research, Seoul, Korea
}

보청기 착용 효과 측정을 위한 음장어음인지평가의 임상적 중요성

고요셉 ${ }^{1,2} \cdot$ 이재희 ${ }^{1,3}$

한림국제대학원대학교 청각언어치료학과, ${ }^{1}$ 성가롤로병원, ${ }^{2}$ 청각언어연구소 ${ }^{3}$

\footnotetext{
Received January 27, 2020

Revised May 8, 2020

Accepted July 20, 2020

Address for correspondence

Jae Hee Lee, PhD

Department of Audiology and

Speech-Language Pathology,

HUGS Center for Hearing

and Speech Research,

Hallym University of Graduate

Studies, 427 Yeoksam-ro,

Gangnam-gu, Seoul 06197, Korea

Tel $+82-2-2051-4952$

Fax $+82-2-3451-6618$

E-mail leejaehee@hallym.ac.kr
}

Background and Objectives Although sound-field speech recognition test is an essential evaluation method to verify the benefit of hearing aids, the aided sound-field speech recognition test has not been used as a standard audiometric protocol. This study investigated whether a traditional measure of unaided speech recognition measured at an individual's most comfortable level (MCL) can predict aided speech recognition performance and the benefit of hearing aids.

Subjects and Method One hundred twenty-one ears ( 72 adult hearing aid users) with moderate, moderately severe, and severe degrees of hearing loss were tested. The word recognition score (WRS) and sentence recognition score (SRS) were measured at MCLs using earphones (earphone WRS and earphone SRS). From the sound-field speech audiometry, both unaided and aided WRS and SRS were evaluated at an average conversational speech level (at $65 \mathrm{~dB}$ SPL) using a loudspeaker (located at $0^{\circ}$ azimuth, $1 \mathrm{~m}$ ). This study determined the differences between earphone scores (at MCL) and aided recognition scores (at $65 \mathrm{~dB}$ SPL), which is known as earphone to aided difference (EAD). Also, the hearing aid benefit was simply derived by differences between the unaided and aided scores, both measured at $65 \mathrm{~dB}$ SPL.

Results The differences between the unaided and aided scores were significantly lower with a higher degree of hearing loss, yet the earphone scores measured at MCLs did not differ across varied hearing loss. More than half of the tested ears had the EAD of greater than $\pm 10 \%$. The ears with a higher degree of hearing loss tended to have +EAD (earphone score $>$ aided score), whereas the ears with less hearing loss showed -EAD (earphone score $\leq$ aided score). The earphone score measured at MCLs was not a predominant contributor to predict either aided performance or hearing aid benefit.

Conclusion Clinicians should not assume that the unaided speech recognition score measured with earphones at MCL can accurately predict aided speech recognition or the benefit of hearing aids. Instead, it is crucial to directly assess aided sound-field speech recognition performance at a conversational speech level. Korean J Otorhinolaryngol-Head Neck Surg 2021;64(5):310-20

Key Words Aided speech recognition · Hearing aids · Sound-field test.

This is an Open Access article distributed under the terms of the Creative Commons Attribution Non-Commercial License (https:/creativecommons.org/licenses/by-nc/4.0) which permits unrestricted non-commercial use, distribution, and reproduction in any medium, provided the original work is properly cited. 


\section{서 론}

보청기는 난청인이 사용하는 대표적인 재활 도구로 적절한 소리 증폭을 통해 난청인의 청력 손실을 보상하고 듣기 능력 을 향상시킬 수 있다. 보청기를 적절하게 적합하였는지 객관 적으로 확인(verification)하기 위해 기능이득(functional gain), 실이삽입이득(real-ear insertion gain) 혹은 실이삽입 반응(real-ear insertion response)을 확인하거나 다양한 듣 기 상황에서 보청기 착용 후 어음인지 능력의 개선 정도를 측정한다. ${ }^{1)}$ 그 외에 주관적 평가(validation)를 통해 보청기 착용 후 만족도의 변화, 보청기 착용 전후 음질, 청취노력 및 주관적 청각장애지수의 변화 등을 확인할 수 있다. 현재까지 보청기 착용의 효과를 측정하기 위해 다양한 객관적, 주관적 평가 도구가 개발되었으나 임상에서 모든 도구를 적용하는 것은 어렵다. 따라서 Humes ${ }^{1)}$ 는 다양한 측정 도구 중 어떠한 평가를 포함하는게 적절한지 주성분 요인분석을 시행하였다. 분석 결과 보청기 착용 후 어음인지 능력의 개선 정도(보청기 착용 효과)를 측정하고, 보청기 착용 후 소리 음질과 보청기 만족도에 대한 주관적 평가를 시행할 것을 권장하였다.

보청기 착용 상태에서 음장검사를 통해 시행하는 어음청 각검사는 주로 보청기 착용으로 어음인지 능력이 개선되는 효과가 있는지 파악하는 데 목적을 둔다. 따라서 보청기 선택 전 실시하는 어음청각검사와는 다른 제시 레벨 혹은 제시 방 법을 적용해야 한다. ${ }^{2)}$ 예를 들어 난청의 진단 혹은 보청기 선 택의 목적으로 어음청각검사를 시행할 경우 헤드폰 혹은 삽 입이어폰을 통해 대상자의 쾌적레벨(most comfortable loudness level, MCL)에서 어음을 제시하여 양 귀의 인지도를 각 각 측정한다. 그러나 보청기 착용의 효과를 측정하기 위해서 는 이어폰이 아닌 라우드스피커를 통해 음장어음청각검사 (sound-field speech audiometry)를 시행해야 한다. 특히 음 장검사의 환경이 결과에 영향을 미칠 수 있으므로 국제 표준 에서 규정한 라우드스피커의 거리, 높이, 방향 등을 고려한 환경에서 검사를 진행하는 것이 중요하다. 예를 들면 2009년 국제표준 ISO 8253-2,') 2019년 British Society of Audiology 가이드라인에 의하면 ${ }^{4}$ 역제곱법칙(inverse square law) 효 과를 최소화하기 위해 라우드스피커를 청자로부터 최소 $1 \mathrm{~m}$ 이상의 거리에 두어야 하고, 자리에 앉은 청자의 머리 높이에 위치시키며, 기준점을 향하게 놓아야 한다.

음장어음청각검사에서는 보청기 착용 전후 일상적인 대화 상황에서의 의사소통 능력의 변화를 알아보는 것이 주목적 이다. 따라서 음장어음청각검사 시 대상자의 MCL이 아닌 보 통 대화음 레벨에서 어음을 제시하여 보청기 착용 전후 인지 도의 변화를 확인해야 한다. 국제표준 IEC 60118-15)에서는
30, 65, 99 퍼센타일에 해당하는 대화음 레벨을 $55,65,80$ $\mathrm{dB} \mathrm{SPL}$ (작은 대화음, 보통 대화음, 큰 소리 대화음)로 나타 내고 있고, 선행 연구에서도 보청기 착용 후 보청기의 적합성 을 파악하기 위해 50 75 dB SPL과 같은 보통 대화음 강도 전후에서 목표 어음을 제시하고 실제로 난청인이 어려움을 겪는 듣기 상황에서 인지도를 측정하였다.) 한국어 대화음 레벨을 분석한 결과 작은, 보통, 큰 소리에 해당하는 대화음 레벨이 각각 대략 $60,65,80 \mathrm{~dB} \mathrm{SPL}$ 이므로 ${ }^{7)}$ 보청기 착용 후 보통 대화음 레벨(normal conversational speech level)인 $65 \mathrm{~dB} \mathrm{SPL}($ 약 $45 \mathrm{~dB} \mathrm{HL}$ )에서 음장어음청각검사를 측정하 는 것이 필요하다.

그러나 국내 임상에서는 대상자의 MCL에서 단어인지도 만 측정하고 보청기 착용 후 음장어음청각검사를 따로 시행 하지 않거나, 보청기 착용 후 보통 대화음 레벨이 아닌 대상 자의 보청기 착용 후 $\mathrm{MCL}$ (aided MCL) 등의 레벨에서 검사 를 시행하는 등 보청기 착용 효과를 측정하기 적절하지 않은 방법을 사용하는 경우가 있다. 보청기 착용 전 대상자의 개인 별 $\mathrm{MCL}$ 에서 어음인지도를 측정하는 이유는 추후 대상자가 적절하게 적합된 보청기를 통해 어음을 편안하게 잘 들을 수 있게 되었을 때 이 정도 어음인지능력을 보일 것이라고 가정 해왔기 때문이다. 위의 가정이 맞다면 MCL에서 측정한 어 음인지도와 보장구 착용 후 보통 대화음레벨에서 측정한 어 음인지도 간 큰 차이가 없어야 한다. 최근 선행연구 ${ }^{8-11)}$ 에서 다양한 종류의 청각 보조기기(보청기, 인공와우 혹은 중이이 식) 사용자를 대상으로 한 결과, 보조기기 착용 전 혹은 이식 전 이어폰을 통해 $\mathrm{MCL}$ 에서 측정한 난청인의 단어인지도만 으로 보조기기 착용 후의 어음인지도를 설득력 있게 예측하 지 못하였다. 그러나 선행 연구에서는 다양한 난청 정도의 귀 를 대상으로 하지 않았으므로 보다 다양한 난청 정도를 포함 하는 것이 필요하다.

따라서 본 연구에서는 보청기를 착용 중인 중도, 중고도, 고도 난청 귀를 대상으로 기존에 보청기 착용 전 주로 측정 하는 대상자 MCL에서의 어음인지도를 구하였고, 추가로 보 통 대화음 레벨에서 보청기 착용 전후 음장어음청각검사를 측정하여 어음인지도를 비교하였다. 이를 통해 보청기 착용 전 $\mathrm{MCL}$ 에서 구한 어음인지도가 보청기 착용 후 보통 대화음 레벨(65 dB SPL)에서 측정한 어음인지도와 어느 정도 차이가 있는지, 보청기 착용 전 측정한 어음인지도로 보청기 착용 후의 어음인지 능력 혹은 보청기 착용 혜택을 예측할 수 있 는지 확인하고자 하였다. 


\section{대상 및 방법}

\section{대 상}

본 연구에서는 보청기를 착용 중인 72명(남성 42 명, 여성 30 명)을 대상자로 선정하였다. 대상자의 평균 연령은 73 세 (40 88세)였고 난청이 지속된 기간은 평균 약 4.9년이었다. 보청기 착용 기간은 평균 5 개월(1개월 6년)이었고 대상자가 양이에 보청기를 착용하는 귀의 경우 두 귀를 각각 검사하였 다. 양이 중 중도에서 고도의 난청 정도를 보이는 귀를 대상 귀로 선택하였기에 심도 난청을 보이는 23 귀는 제외하고 총 121 귀의 결과를 데이터로 분석하였다. 대상 121 귀 모두 공기 전도, 골전도 역치 차이가 $10 \mathrm{~dB}$ 이하인 감각신경성 난청을 보 였고, 이경을 통한 육안 관찰시 외이 및 고막에 이상이 없었다.

121 귀의 3 분법 $(500,1000,2000 \mathrm{~Hz})$ 평균 순음청력역치 (pure-tone threshold average, PTA)를 기준으로 중도(41 55 $\mathrm{dB} \mathrm{HL})$, 중고도(56 70 dB HL), 고도(71 90 dB HL) 난청 귀로 분류하였다. 121 귀 중 26 귀는 중도 난청(moderate HL), 51귀는 중고도 난청(moderately severe HL), 44귀는 고도 난 청(severe HL)을 보였다. 보청기 착용 전 3분법 PTA는 중도, 중고도, 고도 난청 귀 순서대로 $48.85 \mathrm{~dB} \mathrm{HL}, 63.06 \mathrm{~dB} \mathrm{HL}$, $77.39 \mathrm{~dB}$ HL이었으며, 보청기 착용 후 3 분법 PTA는 위 순서 대로 $36.85 \mathrm{~dB} \mathrm{HL}, 47.30 \mathrm{~dB} \mathrm{HL}, 53.89 \mathrm{~dB}$ HL이었다(Table 1). 중도, 중고도, 고도 난청 귀의 250 8000 Hz 내 옥타 브 단위 주파수별 보청기 착용 후 청력역치는 Fig. 1에 제시 하였다. 일원분산분석 결과 난청 정도별 대상자의 나이, 보청 기 착용 기간, 난청 기간 등에 유의한 차이가 없었다 $(p>0.05)$.

보청기 착용에 대한 만족도를 파악하기 위해 국제표준보 청기효과지수(Korean international outcome inventory for hearing aids ${ }^{12}$ 설문을 사용하여 주관적인 보청기 만족도를 측정하였고, 보청기로 전달된 소리에 대해 주관적 음질 평가 ${ }^{13)}$ 를 시행하였다(10점이면 각 음질영역에서 매우 그렇다, 5점이 면 보통/편안함을 의미). 중도, 중고도, 고도 난청 정도에 따라 보청기 착용 전후 측정한 PTA, 사용하고 있는 보청기에 대한
주관적 만족도 및 음질 평가 결과를 Table 1에 나타내었다. 각 대상자가 가장 편안하다고 선호하는 보청기 적합 상태에서 연구에 참여하였으며, 연구에 참여하기 전 대상자들에게 본 연구의 목적, 방법 및 진행 절차에 대한 설명을 제공하였으며 참여자들의 동의 후에 연구를 진행하였다(\#IRB: 8620000).

\section{검사 절차}

모든 실험은 소음허용 수준(ISO 8253-1:2010) ${ }^{14)}$ 을 만족하 는 방음실에서 실시하였다. 어음청각검사를 위해 전기음향학 적 교정이 이루어진 청력검사기(Aurical, GN-Otometrics, Lautrupbjerg, Denmark), 이어폰(TDH-39P, Telephonics, Farmingdale, NY, USA), 노트북(gram, LG electronics, Seoul, Korea)을 사용하였다. 음장어음청각검사를 위해 국제 표준 ISO 8253-23)와 British Society of Audiology 가이드라 인)에 따라 라우드스피커(SC-M53, DENON, Japan)를 청자 로부터 1미터 떨어진 곳에 머리 높이에 위치하여 사용하였다.

본 연구에서는 아래와 같이 어음인지도를 총 6 회 측정하였 다. 먼저, 보청기 착용 전 이어폰을 통해 대상자 개인별 $\mathrm{MCL}$ 에서 단어와 문장을 제시하여 옳게 인지한 단어 혹은 문장

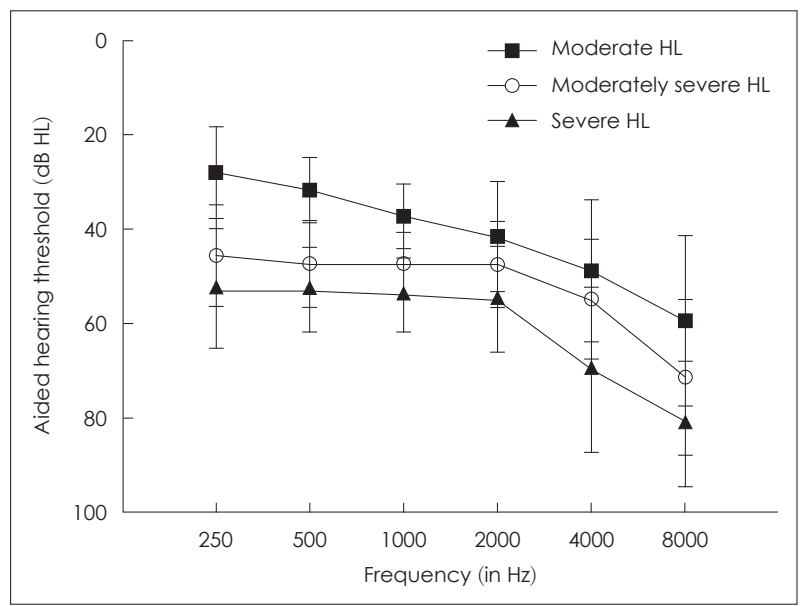

Fig. 1. Mean aided hearing thresholds from 250 to $8000 \mathrm{~Hz}$ of test ear. Error bar: standard deviations.

Table 1. Audiologic and subjective questionnaire information of ears with moderate, and moderately severe, and severe hearing loss

\begin{tabular}{lccc}
\hline & Moderate $\mathrm{HL}(\mathrm{n}=26)$ & Moderately severe $\mathrm{HL}(\mathrm{n}=51)$ & Severe HL $(\mathrm{n}=44)$ \\
\hline Unaided PTA (dB HL) & $48.85(5.26)$ & $63.06(4.16)$ & $77.39(5.52)$ \\
Aided PTA (dB HL) & $36.85(5.48)$ & $47.30(5.47)$ & $53.89(6.94)$ \\
Subjective satisfaction with hearing aid & $24.92(2.87)$ & $26.75(3.67)$ & $27.89(3.25)$ \\
$\quad$ performance (K-IOI-HA) & & & $4.84(0.83)$ \\
Perceived sound quality (loudness) & $5.08(0.75)$ & $4.35(1.75)$ & $4.90(0.71)$ \\
Perceived sound quality (sharpness) & $4.10(1.90)$ & $4.49(1.85)$ & $4.86(1.81)$ \\
Perceived sound quality (pleasantness) & $4.92(1.76)$ & & \\
\hline
\end{tabular}

Data are presented as mean (standard deviation). PTA: pure-tone threshold average, K-IOI-HA: Korean international outcome inventory for hearing aids, HL: hearing loss 
내 중심 단어를 기준으로 기준으로 단어인지도(word recognition score, WRS)와 문장인지도(sentence recognition score, $\mathrm{SRS}$ )를 도출하였다(이하 earphone WRS와 earphone SRS 라 칭함). 보청기를 착용하고 보통 강도의 대화를 잘 인지하 는지 측정하기 위해서는 MCL이 아닌 보통 대화음 레벨에서 어음을 제시하는 것이 중요하므로 ${ }^{57,15)}$ 보청기를 미착용한 상태에서 라우드스피커를 통해 단어와 문장을 한국어 보통 대화음 레벨인 $65 \mathrm{~dB} \mathrm{SPL}(\text { 약 } 45 \mathrm{~dB} \mathrm{HL})^{7)}$ 에서 제시하여 보 청기 착용 전 단어인지도(이하 unaided WRS라 칭함)와 문 장인지도(이하 unaided SRS라 칭함)를 측정하였고, 보청기 착용 상태에서 동일 제시 레벨 및 방법을 통해(65 dB SPL, 라우드스피커) 단어인지도(이하 aided WRS라 칭함)와 문장 인지도(이하 aided SRS라 칭함)를 구하였다. 요약하면 보청 기 착용 전 $\mathrm{MCL}$ 에서 earphone WRS와 earphone SRS 측정, 보청기 착용 전후 보통 대화음 레벨(65 dB SPL)에서 unaided WRS, unaided SRS, aided WRS, aided SRS를 측정하였다. 음장 검사 시 비대칭성 난청으로 검사 귀가 아닌 반대쪽 귀로 어음을 들을 수 있는 경우에는 이어폰(TDH-39P)을 통해 반 대쪽 귀에 차폐 소음을 제시하였다.

본 연구의 실험 특성상 어음청각검사를 반복 시행하게 되 므로 학습효과를 막기 위해 한국어음청각검사 ${ }^{16)}$ 도구 내 서 로 다른 단음절어 및 문장 목록(list 1 3)을 사용하였으며, 검 사자의 육성이 아닌 녹음된 음원을 사용하였다. 녹음된 음원 을 사용할 경우 25 개 혹은 50 개 단어를 사용하여도 신뢰도 있는 WRS를 구할 수 있음을 고려하여 ${ }^{17}$ 본 연구에서는 WRS 측정시 25 개의 단어를 제시하고 정반응한 단어를 백분율 $(\%)$ 로 환산하여 점수를 계산하였다. 검사-재검사 신뢰도를 검 증한 한국표준문장표를 이용하여 목록당 40 개의 중심 단어 중 정반응한 단어 수를 기준으로 점수화(keyword scoring) 하였다. ${ }^{18)}$ 대상자는 실험 참여를 위해 1 회 방문하였으며, 검사 시간은 약 40 분 가량 소요되었다.

\section{데이터 분석}

수집된 결과는 SPSS version 25.0(IBM Corp., Armonk, NY, USA) 소프트웨어를 이용하여 분석하였고, 모든 통계 분 석은 유의 수준 0.05 미만에서 검증하였다. Earphone WRS, earphone SRS, unaided WRS, unaided SRS, aided WRS, aided SRS를 기술통계하였고, 보청기 착용 전 이어폰을 통해 $\mathrm{MCL}$ 에서 측정한 어음인지도(earphone score)와 보청기 착 용 후 음장어음청각검사를 통해 $65 \mathrm{~dB}$ SPL에서 측정한 인지 도(aided score)와의 차이값(earphone to aided difference, $\mathrm{EAD})$ 을 구하였고, 보청기 착용 전후 구한 인지도 차이값을 통해 보청기 혜택 정도를 구하였다(HA benefit=aided score- unaided score). Kolmogorov-Smirnov 검증 결과 정규분포 를 따르는 데이터의 경우 일원분산분석을 통해 난청 정도별 인지도뿐 아니라 $\mathrm{EAD}$, 보청기 혜택 정도를 비교하였고, 유 의한 주효과로 다중비교가 필요한 경우 1 종 오류의 증가를 조정하기 위해서 Bonferroni correction을 적용하였다. 정규 분포를 따르지 않는 데이터의 경우 Kruskal-Wallis 검증과 Mann-Whitney U 검증을 통해 주효과와 다중비교를 시행 하였다. 마지막으로 단계적 다중선형 회귀분석을 통하여 임 상 현장에서 이어폰을 통해 MCL에서 주로 측정하는 어음인 지도(earphone score)로 aided score 혹은 보청기 혜택 정도 를 예측 혹은 설명할 수 있는지 확인하였다.

\section{결 과}

\section{난청 정도에 따른 평균 어음인지도 및 차이값 비교}

Table 2는 중도, 중고도, 고도 난청 귀의 평균 어음인지도와 평균 $\mathrm{EAD}$ 및 보청기 혜택 정도, 각 수치의 표준편차와 범위 를 보여준다. 먼저 보청기 착용 전 MCL에서 측정한 earphone WRS를 살펴보면, 중도, 중고도, 고도 난청 정도의 순서대로 평균 72.92\%, 65.88\%, 60.45\%였고, earphone SRS는 동일 순 서대로 평균 $80.46 \%, 71.04 \%, 66.48 \%$ 였다. 보청기 착용 전 보 통 대화음 레벨( $65 \mathrm{~dB} \mathrm{SPL})$ 에서 측정한 unaided WRS는 중 도, 중고도, 고도 난청 정도 순서대로 평균 $53.54 \%, 23.31 \%$, $8.52 \%$ 였고, unaided SRS는 평균 $57.31 \%, 25.02 \%, 7.98 \%$ 였 다. 보청기 착용 후 동일 레벨에서 제시한 aided WRS는 난청 정도 순서대로 평균 86.00\%, 69.33\%, 57.27\%였고, aided SRS 는 평균 $88.81 \%, 70.88 \%, 59.57 \%$ 였다. 일원분산분석 결과 earphone WRS와 earphone SRS를 제외한 모든 어음인지 도 결과에서 난청 정도에 따른 주효과가 유의하였고 $(p<0.05)$, unaided score의 다중비교 결과에서는 중도보다는 중고도 난청 혹은 고도 난청 귀가, 중고도 난청 귀보다는 고도 난청 귀가 유의하게 저하된 인지도를 보였다. Aided score의 다중 비교 결과에서는 중도보다는 중고도 난청 혹은 고도 난청 귀 가 유의하게 저하된 인지도를 보였고, 중고도와 고도 난청 귀 의 aided score 범위가 상당히 넓어 유의한 차이를 보이지 않 았다.

보청기 착용 전 MCL에서 구한 earphone score와 보청기 착용 후 $65 \mathrm{~dB}$ SPL에서 측정한 aided score의 차이값(EAD) 을 확인하였다. 최근 선행연구에서도 본 연구와 유사하게 earphone score, aided score를 각각 구하였고, earphone score>aided score인 경우는 +EAD로, earphone score $\leq$ aided score인 경우는 $-\mathrm{EAD}$ 로 분류하였다. ${ }^{8-10)}$ 본 연구에서 는 WRS와 SRS를 모두 측정하였으므로 WRS를 기준으로 한 


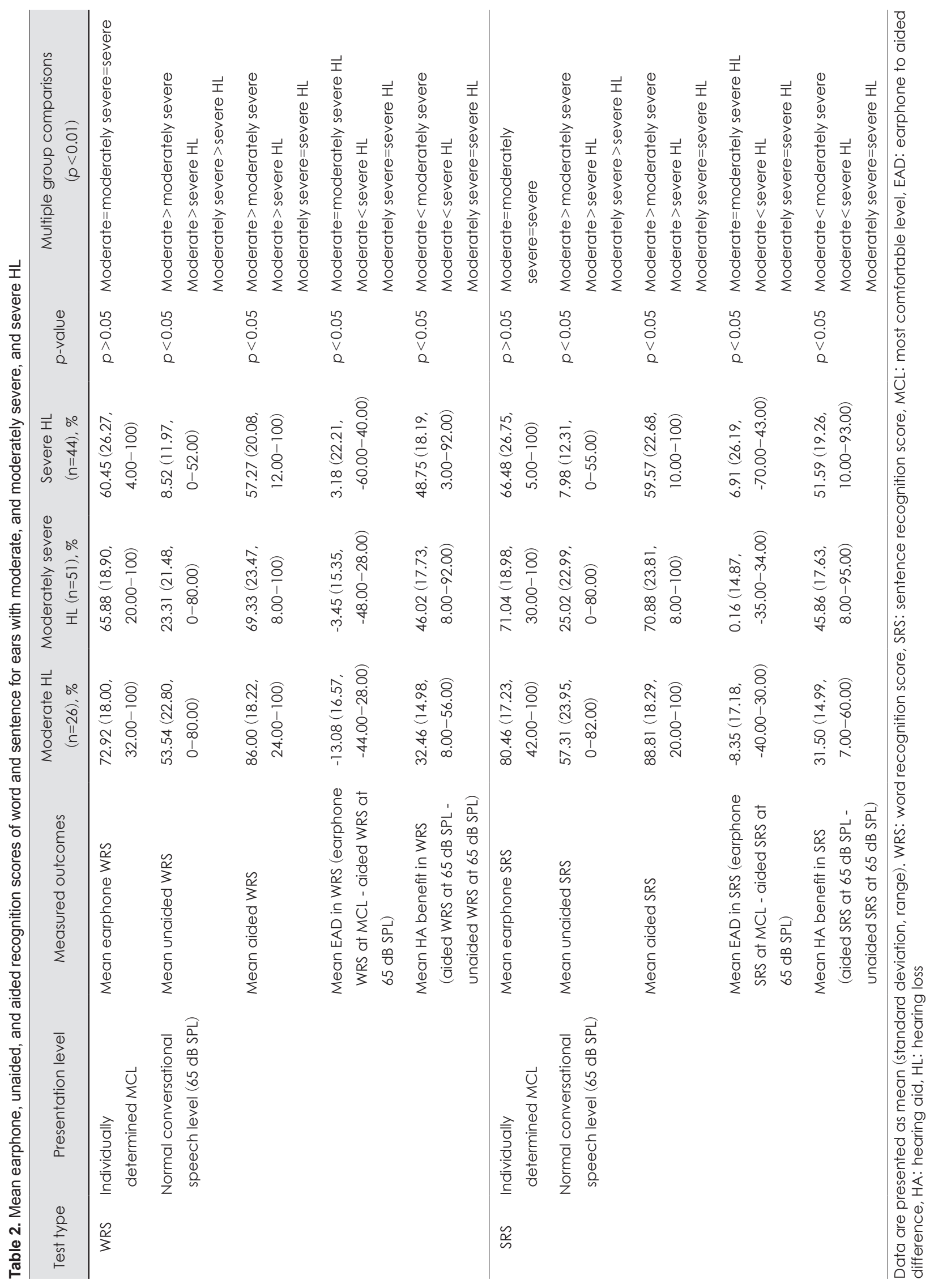


$\mathrm{EAD}, \mathrm{SRS}$ 를 기준으로 한 $\mathrm{EAD}$ 를 각각 확인하였다. WRS를 기준으로 한 평균 $\mathrm{EAD}$ 는 중도, 중고도, 고도 난청 정도의 순 서대로 $-13.08 \%,-3.45 \%, 3.18 \%$ 였으므로 고도 난청의 경우 보청기 착용 전 개인의 $\mathrm{MCL}$ 에서 측정한 $\mathrm{WRS}($ 약 $60 \%)$ 가 보청기 착용 후 $\mathrm{WRS}($ 약 $57 \%$ )보다 평균적으로 약 $3 \%$ 가량 더 컸다. SRS를 기준으로 한 $\mathrm{EAD}$ 는 동일 순서대로 $-8.35 \%$, $0.16 \%, 6.91 \%$ 였으므로 WRS와 마찬가지로 SRS에서도 고도 난청의 경우 보청기 착용 전 측정한 $\mathrm{SRS}($ 약 $67 \%$ )가 보청기 착용 후 $\mathrm{SRS}($ 약 $60 \%$ )보다 평균 7\% 가량 더 컸음을 알 수 있 었다. 일원분산분석 결과 난청 정도에 따라 $\mathrm{EAD}$ 값이 유의하 게 달랐고 $(p<0.05)$, 다중비교 결과 중도와 중고도 난청 귀 간, 중고도 난청 귀와 고도 난청 귀 간 유의한 차이는 없었으나 중 도 난청 귀보다 고도 난청일수록 $\mathrm{EAD}$ 값이 유의하게 더 컸다. 마지막으로 동일 레벨(65 dB SPL)에서 측정한 보청기 착용 전후 인지도를 통해 보청기 혜택을 계산하였다. 먼저 중도, 중 고도, 고도 난청 순서대로 $\mathrm{WRS}$ 를 기준으로 보청기 혜택 정 도를 확인한 결과(aided WRS-unaided WRS) 보청기 착용 후 약 32\%(8 56\%), 46\%(8 92\%), 49\%(3 92\%) 가량 WRS 가 증가하였다. SRS를 기준으로 보청기 혜택을 확인한 결과 (aided SRS-unaided SRS), 난청 정도별 순서대로 문장인지 도가 보청기 착용 후 약 32\%(7 60\%), 46\%(8 95\%), 52\% (10 93\%) 가량 향상하였다. 평균적으로는 최소 $30 \%$ 부터 최 대 50\% 가량 증가하였다고 볼 수 있지만, 상당히 넓은 범위 (최소 $3 \%$ 최대 $95 \%$ 향상)를 고려하였을 때 개인간 보청기 혜택의 범위가 큼을 알 수 있다(표준편차와 범위는 Table 2 참조). 난청의 정도가 커질수록 보청기 혜택의 정도가 커지는 경향이 관찰된 이유는 aided score-unaided score와 같이 단순한 차이 값을 통해 보청기 혜택을 구했으므로 심도 난청 일수록 현저히 낮은 unaided score가 결과에 반영되었다고 보아야 할 것이다. 통계분석 결과 난청 정도에 따라 보청기 혜택 정도가 유의하게 달랐고 $(p<0.05)$, 다중비교 결과 중고 도와 고도 난청 귀 간 보청기 혜택 정도는 유의하게 다르지 않았으나 다른 비교 결과에서는 유의한 차이가 있었다.

\section{난청 정도에 따른 어음인지도 분포 비교}

Fig. 2는 중도, 중고도, 고도 난청 귀를 대상으로 측정한 earphone WRS와 SRS(Fig. 2A and B), unaided WRS와 SRS(Fig. 2C and D), aided WRS와 SRS(Fig. 2E and F)의 분포를 보여준다. 그림을 통해 알 수 있듯이 earphone score, aided score에서 중도 난청에 비해 중고도, 고도 난청일수록 최소 최대 범위가 넓고 그 범위를 넘는 다수의 이상치가 확 인되었다.

Fig. 3은 중도, 중고도, 고도 난청 귀를 대상으로 측정한
EAD(earphone score-aided score)(Fig. 3A and C)와 보청 기 혜택(aided score-unaided score)(Fig. 3B and D)의 분포 를 보여준다. 측정한 인지도가 WRS 혹은 SRS든 상관없이 난청의 정도가 심할수록 $\mathrm{EAD}$ 값이 증가하고 $\mathrm{EAD}$ 의 분포 가 더 넓었다. 보청기 혜택 정도 또한 난청의 정도가 심할수 록 점차 증가하는 경향이 있었으며, 중도에 비해 중고도 혹은 고도 난청일수록 보청기 혜택 정도의 범위가 넓었다.

$\mathrm{EAD}$ 의 분포가 넓다는 것은 임상 현장에서 주로 측정하는 $\mathrm{MCL}$ 에서 구한 earphone score와 보통 대화음 레벨에서 측 정한 aided score 간 차이가 큼을 의미한다. 구체적으로 보청 기 착용 전 $\mathrm{MCL}$ 에서 구한 어음인지도가 보청기 착용 후 측 정한 어음인지도와 어느 정도 차이가 있는지 확인하기 위해 121 귀의 EAD 분포를 히스토그램을 통해 확인하였다(Figs. 4 and 5). Fig. 4는 중도, 중고도, 고도 난청 정도 별로 WRS 를 기준으로 구한 $\mathrm{EAD}$ 의 분포를 보여준다. 먼저 중도 난청의 경우(Fig. $4 \mathrm{~A}$ ) 26 귀 중 13 귀가 $\pm 10 \%$ 이하의 $\mathrm{EAD}$ 를 보였고, 전반적인 분포를 살펴보았을 때는 $+\mathrm{EAD}$ 보다는 $-\mathrm{EAD}$ 를 보 인 경우(약 $92 \%$ 가량)가 더 많았다. 중고도 난청의 경우(Fig. 4B) 51 귀 중 27 귀가 $\pm 10 \%$ 이하의 $\mathrm{EAD}$ 를 보였고, 전반적으 로 $+\mathrm{EAD}$ 보다는 $-\mathrm{EAD}$ 를 보이는 경우가 더 많았다. 즉 중도, 중고도 난청일수록 MCL에서 측정한 earphone score보다 보 청기 착용 후 $65 \mathrm{~dB} \mathrm{SPL}$ 에서 측정한 aided score가 더 높은 경우(earphone score<aided score)가 더 많았다. 고도 난청 의 경우(Fig. $4 \mathrm{C}$ ) 44 귀 중 18 귀만이 $\pm 10 \%$ 이하의 $\mathrm{EAD}$ 를 보 였고, 중도, 중고도 난청과는 다르게 $-\mathrm{EAD}$ 보다는 $+\mathrm{EAD}$ 를 보이는 경우가 더 많았다.

Fig. 5는 SRS를 기준으로 구한 $\mathrm{EAD}$ 의 분포를 난청 정도 별로 구분하여 보여준다. 중도 난청의 경우(Fig. $5 \mathrm{~A}$ ) 26 귀 중 16 귀가 $\pm 10 \%$ 이하의 $\mathrm{EAD}$ 를 보였고 전반적으로 $-\mathrm{EAD}$ 를 보이는 귀가 더 많았다. 중고도 난청의 경우(Fig. 5B) 51귀 중 22 귀는 $\pm 10 \%$ 이하의 $\mathrm{EAD}$ 를 보였으나, 고도 난청의 경우 44 귀 중 14 귀만이 $\pm 10 \%$ 이하의 $\mathrm{EAD}$ 를 보였고 고도 난청일 수록 $-\mathrm{EAD}$ 보다 $+\mathrm{EAD}$ 의 분포가 더 많았다. 즉, 고도 난청일 수록 보청기 착용 후 구한 aided score가 MCL에서 측정한 earphone score에 도달하지 못한 경우가 많아(earphone score $>$ aided score) $+\mathrm{EAD}$ 의 분포가 더 컸음을 확인하였다.

요약하면 중도와 중고도 난청의 경우 보청기 착용 전 $\mathrm{MCL}$ 에서 측정한 어음인지도보다 실제 보청기 착용 후 보통 대화 강도에서의 어음인지도가 더 높은 경우가 많았으나, 고도 난 청의 경우 $\mathrm{MCL}$ 에서 측정한 어음인지도보다 실제 보청기 착 용 후 보통 대화 강도에서의 어음인지도가 더 낮은 경우가 많았다. 


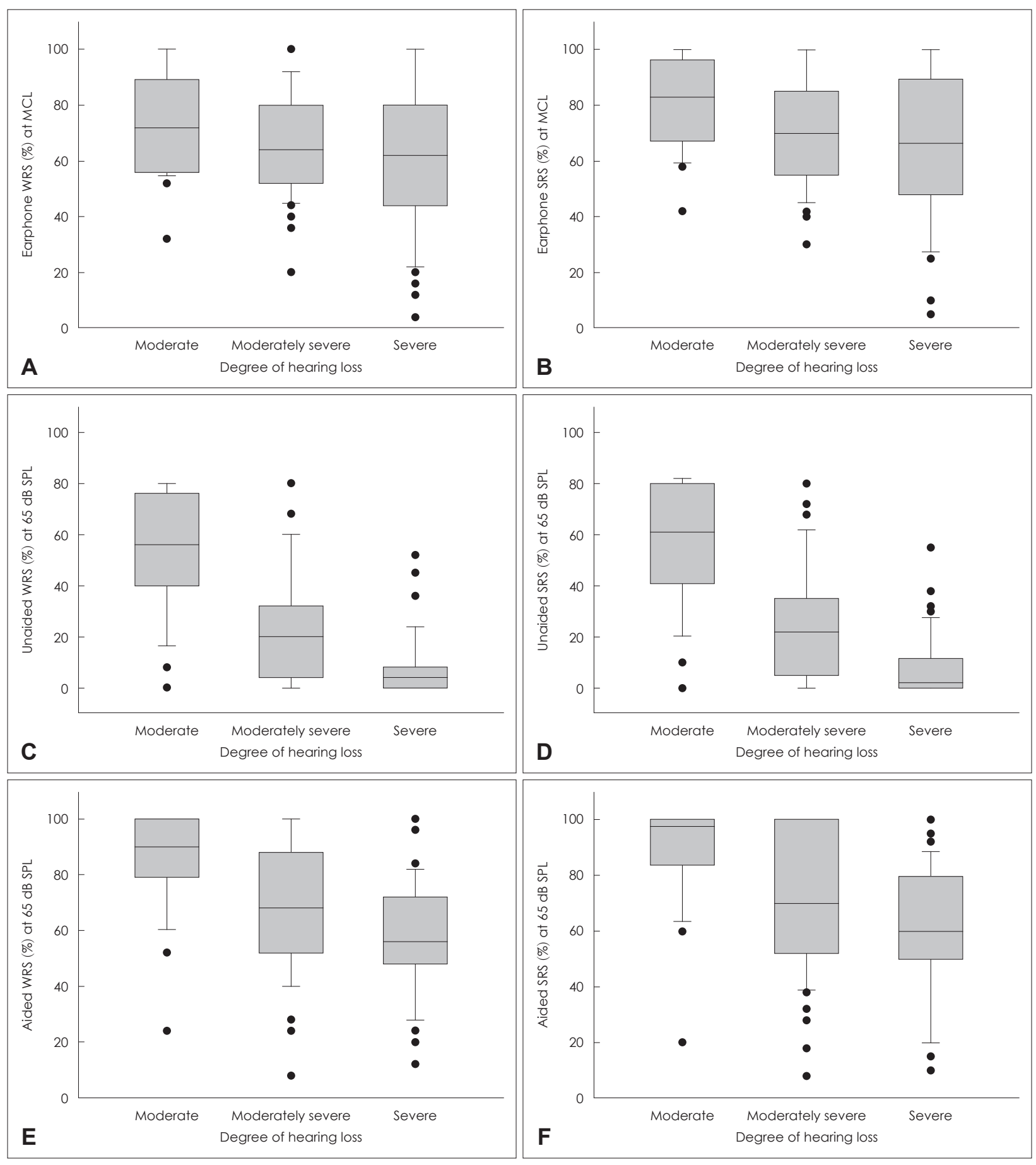

Fig. 2. Boxplots of earphone WRS (A) and SRS (B), unaided WRS (C) and SRS (D), and aided WRS (E) and SRS (F) (boxes: the 25th and 75th percentiles, solid lines: median value, error bars: the 10th and 90th percentiles, circles: outliers). WRS: word recognition score, SRS: sentence recognition score.

\section{단계적 다중선형 회귀분석}

단계적 다중선형 회귀분석을 통해 대상 귀의 보청기 착용 후 순음청력역치, 보청기 사용 및 난청 기간, earphone score (MCL), unaided score(65 dB SPL) 결과 중 aided score(65 $\mathrm{dB} \mathrm{SPL}$ )를 설명하는 데 가장 설명력이 높은 변수를 확인하
였다. Aided score를 종속변수로 하였을 때 측정한 것이 WRS든 SRS든 상관없이 위에서 열거한 여러 변수 중 가장 설명력이 높은 변수는 unaided score였다(약 52 53\% 가량 설명). 대상 귀의 보청기 착용 후 순음청력역치가 추가로 포함 되었을 경우 11 16\% 가량의 설명력이 증가하였다. MCL에서 

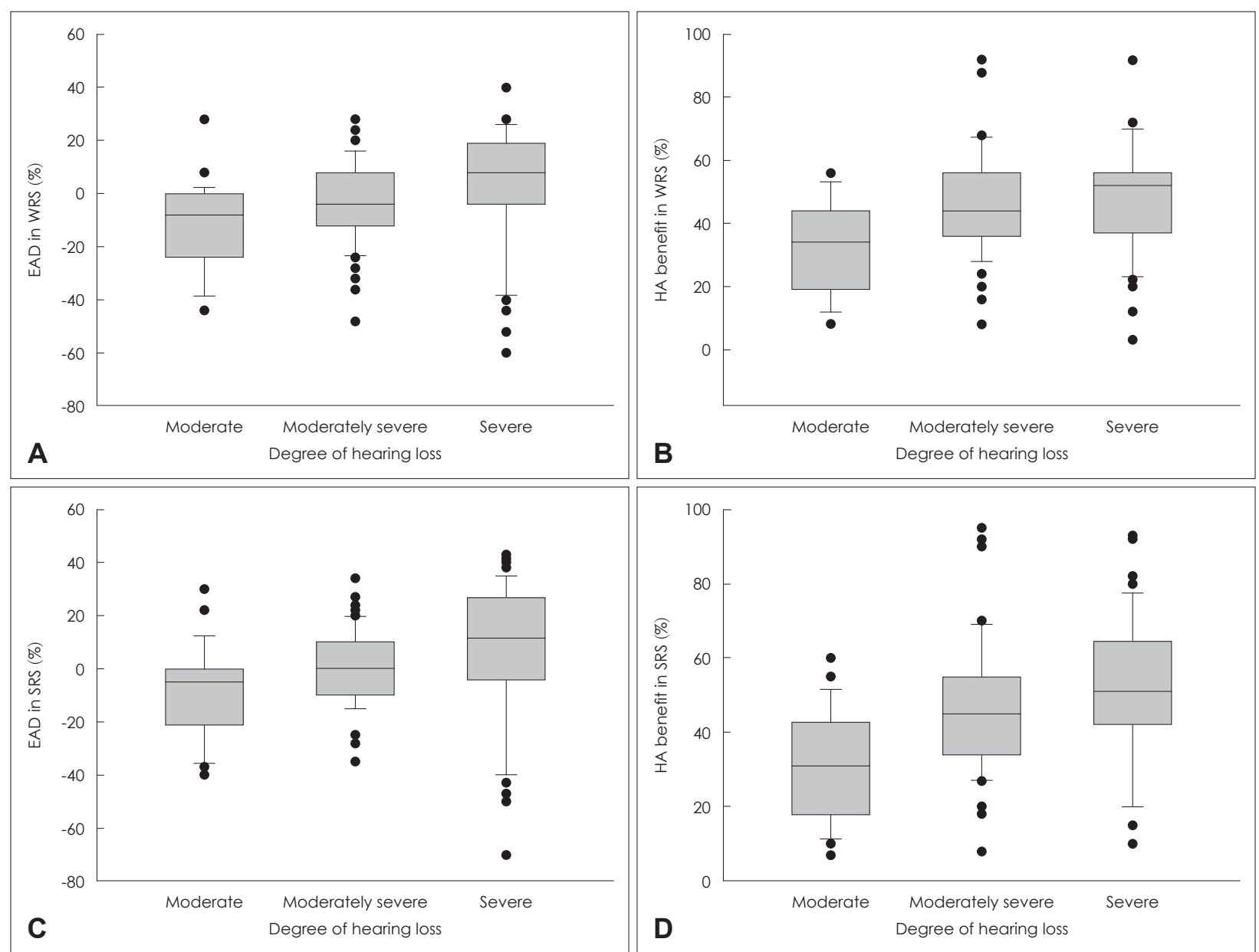

Fig. 3. Boxplots of EAD in WRS (A) and SRS (C), and HA benefits in WRS (B) and SRS (D) (boxes: the 25th and 75th percentiles, solid lines: median value, error bars: the 10th and 90th percentiles, circles: outliers). EAD: earphone to aided difference, WRS: word recognition score, SRS: sentence recognition score, HA: hearing aid.

측정하는 earphone score는 aided score를 유의하게 설명할 수 있는 변수가 아니었다.

보청기 착용 전후 인지도 차이값을 통해 구한 보청기 혜택 정도를 종속변수로 하여 단계적 다중선형 회귀분석을 추가로 시행하였다. 위의 여러 변수 중 보청기 혜택 정도를 설명하는 데 가장 설명력이 높은 변수 역시 unaided score로, 약 21 $24 \%$ 가량 보청기 혜택 정도를 설명할 수 있었으며 earphone score나 aided score는 보청기 혜택 정도를 유의하게 설명할 수 있는 변수가 아니었다. 즉, 임상 현장에서 주로 측정하는 $\mathrm{MCL}$ 에서의 earphone score만으로는 보청기 착용 후의 어음 인지 능력 혹은 보청기 혜택 정도를 신뢰도 있게 예측하는 데 한계가 있음을 의미한다.

\section{고 찰}

난청인은 보청기 착용을 통해 청각 손실을 보상받고 일상 생활에서 듣기 능력이 향상하는 등 다양한 혜택을 가질 수
있다. 그러나 유사한 난청 정도와 형태를 가졌더라도 보청기 착용으로부터 얻는 혜택 정도는 상이하다. ${ }^{19-21)}$ 개개인간 보청 기 혜택의 정도가 매우 다양하므로 다양한 검사 도구를 통해 목표 어음의 제시 레벨, 어음 및 배경소음의 종류, 신호대잡 음비, 방향분리 등을 체계적으로 변화하면서 보청기 착용 후 의 어음인지 능력을 측정할 수 있다. ${ }^{1,22)}$ 그러나 임상 현장에서 는 시간 소요가 적으면서 효과적인 방법으로 보청기의 적합 성을 객관적으로 확인(verification)하는 것이 필요하다. 특히 보청기 착용 후 난청인이 일상생활 속 의사소통 능력이 개선 되었는지를 파악하기 위해 음장어음청각검사를 시행하는 것 이 필수적이다. ${ }^{1-2,6)}$

2020년부터 청각장애인 보청기 급여절차에서 반드시 음장 검사를 통해 보청기 검수 확인을 하게 되어 있지만, 급여 보 청기가 아닌 보청기의 경우 임상 현장에 따라 음장검사의 시 행 여부는 매우 다양하다. 보청기 착용 효과를 측정하기 위해 통상적인 검사 절차로 보통 대화음 레벨에서 음장어음청각 검사를 시행하는 곳도 있지만, 보청기 착용 전 대상자의 $\mathrm{MCL}$ 

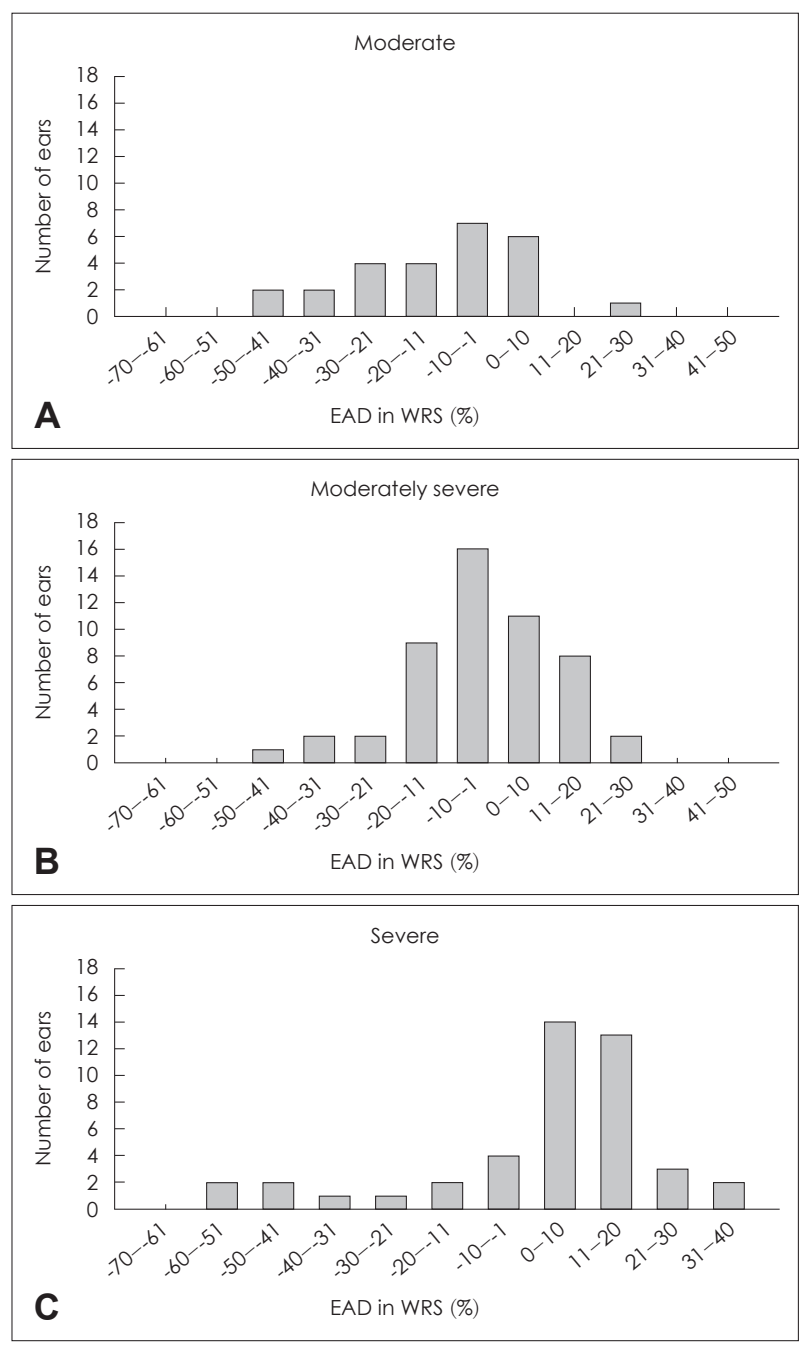

Fig. 4. Distribution of EAD in WRS (\%) for ears with moderate (A), moderately severe (B), and severe degree of hearing loss (C). EAD: earphone to aided difference, WRS: word recognition score.

에서 측정한 단어인지도만을 측정하고 별도로 aided score를 구하지 않는 경우도 있다. 혹은 보청기 착용 후 보통 대화음 레벨이 아닌 보청기 착용 후 $\mathrm{MCL}$ 에서 어음을 제시하는 등 적절하지 않은 방법으로 보청기 착용 효과를 확인하는 경우 가 있어 결과 판독 시 주의할 필요가 있다.

본 연구에서는 중도, 중고도, 고도 난청 귀를 대상으로 현 재 임상에서 주로 측정하는 MCL에서 이어폰을 통해 구하는 어음인지도(earphone score)와 보청기 착용 전후 보통 대화 음 강도에서 측정한 unaided, aided score를 비교하였다. 통 계분석 결과 MCL에서 측정한 earphone score는 난청 정도 에 따라 유의하게 다르지 않았으나 일상 대화음 레벨에서 보 청기 착용 전후 측정한 unaided, aided score는 모두 난청 정도별로 유의한 차이가 있었다. 고도 난청의 경우 earphone score보다 aided score가 평균 약 3 7\% 가량 더 낮았고 개
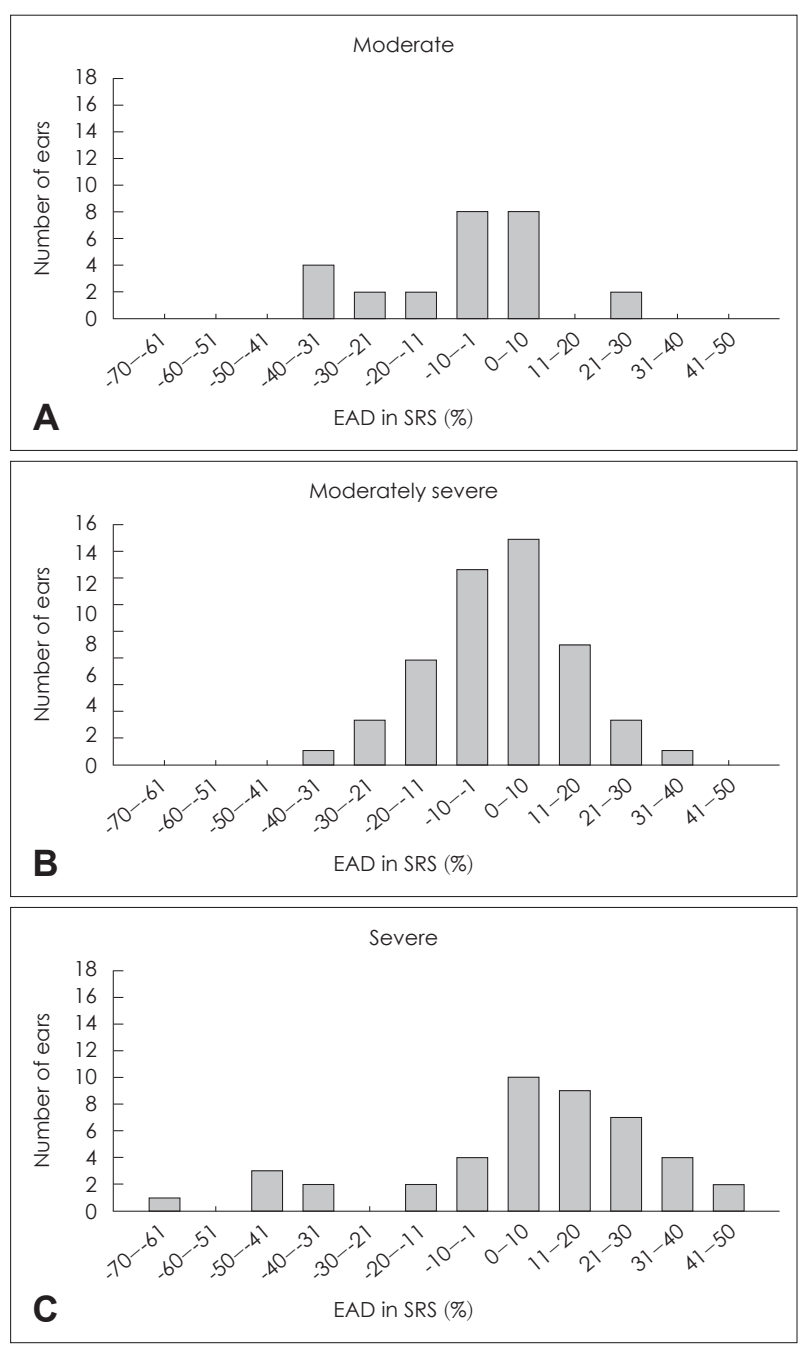

Fig. 5. Distribution of EAD in SRS (\%) for ears with moderate (A), moderately severe (B), and severe degree of hearing loss (C). EAD: earphone to aided difference, SRS: sentence recognition score.

인별로도 +EAD(earphone score>aided score)를 보인 경우 가 더 많았다(Figs. 4 and 5). 보통 크기로 발성한 대화음 레 벨(average level of typical conversational speech)이 대략 $65 \mathrm{~dB}$ SPL(약 $45 \mathrm{~dB} H \mathrm{HL})^{5,7,15}$ 이므로 71 90 dB HL 이내 $\mathrm{PTA}$ 를 보이는 고도 난청 귀가 실제 선호하는 보청기 착용 상 태에서 듣는 어음과 보청기 착용 전 이어폰을 통해 MCL에서 제시한 어음과 차이가 있었을 것이다. 실제로 본 연구의 고도 난청 대상 귀의 경우 보청기 착용 전후 3분법 PTA가 77.39 $\mathrm{dB} \mathrm{HL}, 53.89 \mathrm{~dB}$ HL이었다. MCL에서 측정한 평균 earphone score는 60 67\%(4 100\%)였으며, 보통 대화음 강도 인 $65 \mathrm{~dB} \mathrm{SPL}$ (약 $45 \mathrm{~dB} \mathrm{HL}$ )에서 측정한 보청기 착용 전 unaided score는 평균 10\% 미만(0 55\%), 보청기 착용 후 aided score는 평균 57 60\%(10 100\%)였다. 만약 고도 난청 귀의 청력을 고려하여 일상 대화어음을 충분히 들을 수 있 
게 보청기 이득을 더 증가하였다면 보청기 착용 후 $\mathrm{PTA}$ 는 향상하였을지 모르나 오히려 소리의 변조, 울림 및 누가 현상 등으로 인한 불편함을 야기할 수 있다. 실제로 보청기 착용자 는 순음청력역치를 기준으로 청각 손실을 보상받는 것 외에 소리를 편안하게 들을 수 있게 적합받는 것을 중요 요소로 고려하므로 대상자의 청력역치를 기준으로 하여 적합공식에 서 권장하는 이득보다 더 적은 증폭을 선호하기도 한다. ${ }^{23)}$

앞서 제시한 EAD의 분포(Figs. 4 and 5)와 단계적 다중선 형 회귀분석 결과를 고려하면, 보청기 선택 전 $\mathrm{MCL}$ 에서 측 정한 단어 및 문장인지도를 통해 보청기 착용 후 일상대화를 인지하는 능력을 예측하거나 보청기 혜택 정도를 유의하게 설명하는 데는 한계가 있음에 주의해야 할 것이다. 이와 같은 결과는 보청기 착용자, 인공와우 혹은 중이 이식 대상자를 통 한 선행 연구 결과와 유사하다. ${ }^{8-11)}$ 예를 들어 McRackan 등 ${ }^{8)}$ 은 94명의 양이 대칭성 난청을 가진 보청기 착용자를 대상으 로 earphone WRS을 구하였고, 음장검사를 통해 일상대화 레벨에서 보청기 착용 전후 unaided, aided WRS를 측정하 였다. 본 연구와 유사하게 EAD(earphone WRS-aided WRS) 값을 산출하여 +EAD(earphone WRS>aided WRS)와 -EAD(earphone WRS $\leq$ aided WRS)의 분포를 확인하였다. 분석 결과, 95 명 중 24 명이 $\pm 10 \%$ 이하의 $\mathrm{EAD}$ 를 보였고, 나 머지 71 명은 $-30 \%$ 의 $\mathrm{EAD}$ 부터 $50 \%$ 의 $+\mathrm{EAD}$ 까지 넓은 분 포를 보였다. 그러나 이 연구에서는 난청 정도별 분석을 시행 하지 않아서 난청 정도별 $\mathrm{EAD}$ 값의 변화는 제시하지 않았 다. 인공와우 이식 후보 183명의 208귀를 대상으로 EAD를 확인한 연구에서는 ${ }^{9)}$ earphone WRS와 aided WRS의 비교 결과 $-38 \sim 72 \%$ 까지 넓은 범위의 $\mathrm{EAD}$ 분포를 확인하였다. 91명의 중이 이식 환자를 대상으로 한 연구에서도 ${ }^{10)}$ earphone $\mathrm{WRS}$ 보다 기존에 사용하던 보청기 착용 후 구한 aided WRS 가 중이 이식 후 측정한 aided WRS와 상관성이 더 높음을 밝혔다. 284 명의 인공와우 이식 성인을 대상으로 분석한 결과 에서도 대부분 earphone score보다 aided score가 더 낮았 으며 earphone score의 예측력 또한 높지 않다고 하였다. ${ }^{11)}$

보청기 착용 121 귀를 대상으로 한 본 연구의 결과를 요약 하면 다음과 같다. 현재 임상 현장에서 MCL에서 이어폰을 통해 측정하는 earphone score는 난청의 진단 및 보청기 선 택 시 중요한 정보를 제공하지만 이를 통해 보청기 착용 후 어음인지 능력을 가정하거나 보조기기 혜택을 예측하는 것 은 적절하지 않겠다. 객관적 보청기 적합 확인의 절차로 음장 어음청각검사를 반드시 시행하여 일상대화레벨에서의 의사 소통 능력을 신뢰도 있게 평가하는 것이 중요하겠다. 특히 보 청기 착용 효과 측정 시 보청기 미착용 상태에서의 $\mathrm{MCL}$, 보 청기 착용 상태에서의 $\mathrm{MCL}$ 과 같이 서로 다른 레벨을 사용
하는 것이 아니라 보통 대화음 레벨인 $65 \mathrm{~dB} \mathrm{SPL}$ (약 $45 \mathrm{~dB}$ $\mathrm{HL})$ 을 고려한 동일 레벨에서 보청기 착용 전후 음장어음인 지도를 비교하여야 한다. 본 연구에서 $\mathrm{EAD}$ 범위가 상당히 넓었고 특히 고도 난청일수록 MCL에서 구한 earphone score 보다 보청기 착용 후 aided score가 더 낮은 경우가 많았으 므로 이러한 정보를 고도 난청인의 보청기 적합 및 청능재활 상담 시 적용해볼 수 있겠다.

\section{Acknowledgments}

This work was supported by the Ministry of Education of the Republic of Korea and the National Research Foundation of Korea (NRF-2019S1A5A2A01051014).

\section{Author Contribution}

Conceptualization: Yoseb Ko, Jae Hee Lee. Data curation: Yoseb Ko. Formal analysis: Yoseb Ko. Funding acquisition: Jae Hee Lee. Writing — original draft: Yoseb Ko, Jae Hee Lee. Writing—review \& editing: Jae Hee Lee.

\section{ORCID}

Jae Hee Lee

$$
\text { https://orcid.org/0000-0002-4152-6434 }
$$

\section{REFERENCES}

1) Humes LE. Dimensions of hearing aid outcome. J Am Acad Audiol 1999;10(1):26-39.

2) Jorgensen LE. Verification and validation of hearing aids: Opportunity not an obstacle. J Otol 2016;11(2):57-62.

3) International Organization for Standardization. Acoustics: audiometric test methods. Part 2: Sound field audiometry with puretone and narrow-band test signals (ISO 8253-2:2009). Geneva: International Organization for Standardization;2009.

4) Corrigan D, Horsfall A. Practice guidance: The acoustics of sound field audiometry in clinical audiological applications. BSA [online] 2019 Mar [cited 2020 Jan 27]; Available from: URL: https://www. thebsa.org.uk/resources/guidelines-acoustics-sound-fieldaudiometry-clinical-audiological-applications/.

5) International Electrotechnical Commission. ElectroacousticsHearing Aids-Part 15: Methods for characterising signal processing in hearing aids with a speech-like signal (IEC 60118-15:2012). Geneva: International Electrotechnical Commission;2012.

6) Humes LE, Christensen L, Thomas T, Bess FH, Hedley-Williams A, Bentler R. A comparison of the aided performance and benefit provided by a linear and a two-channel wide dynamic range compression hearing aid. J Speech Lang Hear Res 1999;42(1):65-79.

7) Han YK, Lee K. A study on the Korean conversation speech level and spectrum in sound-treated environment. Audiol Speech Res 2020;16(2):133-39.

8) McRackan TR, Ahlstrom JB, Clinkscales WB, Meyer TA, Dubno JR. Clinical implications of word recognition differences in earphone and aided conditions. Otol Neurotol 2016;37(10):1475-81.

9) McRackan TR, Fabie JE, Burton JA, Munawar S, Holcomb MA, Dubno JR. Earphone and aided word recognition differences in cochlear implant candidates. Otol Neurotol 2018;39(7):e543-9.

10) McRackan TR, Clinkscales WB, Ahlstrom JB, Nguyen SA, Dubno JR. Factors associated with benefit of active middle ear implants compared to conventional hearing aids. Laryngoscope 2018;128(9): 2133-8.

11) Hoppe U, Hocke T, Hast A, Iro H. Maximum monosyllabic score as a predictor for cochlear implant outcome. HNO 2019;67(3):199- 
206.

12) Chu H, Cho YS, Park SN, Byun JY, Shin JE, Han GC, et al. Standardization for a Korean adaptation of the international outcome inventory for hearing aids: Study of validity and reliability. Korean J Otorhinolaryngol-Head Neck Surg 2012;55(1):20-5.

13) Kim HJ, Lee JH, Shim HJ. Effect of digital noise reduction of hearing aids on music and speech perception. J Audiol Otol 2020; 24(4):180-90.

14) International Organization for Standardization. AcousticsAudiometric test methods-Part 1: Pure-tone air and bone coundction audiometry (ISO 8253-1:2010). Geneva: International Organization for Standardization;2010.

15) Lawson GD, Peterson M. Speech audiometry. San Diego, CA: Plural Publishing, Inc;2011.

16) Lee JH, Cho SJ, Kim JS, Jang HS, Lim DH, Lee KW, et al. Korean speech audiometry (KSA). Seoul: Hakjisa;2010.

17) Yoo B, Lee J. Prediction interval of word recognition score using Korean Standard Monosyllabic Word Lists for Adults (KS-MWL-A).
Audiol 2014;10(1):35-42.

18) Lee J, Lee KW, Lee JH, Bahng J, Kim J, Choi CH, et al. Test-retest reliability of sentence recognition score using Korean standard sentence lists for adults (KS-SL-A). Audiol 2015;11(1):17-25.

19) Ochs MT. Revising the routine audiologic test battery to examine sources of interpatient variability. J Am Acad Audiol 1990;1(4): 217-26.

20) Crandell CC. Individual differences in speech recognition ability: Implications for hearing aid selection. Ear Hear 1991;12(6 Suppl): 100S-8S.

21) Cord MT, Leek MR, Walden BE. Speech recognition ability in noise and its relationship to perceived hearing aid benefit. J Am Acad Audiol 2000;11(9):475-83.

22) Lee JH, Yi DW. A comparison of adaptive sentence-in-noise tests. Audiol Speech Res 2017;13(1):9-18.

23) Humes LE. Factors underlying the speech-recognition performance of elderly hearing-aid wearers. J Acoust Soc Am 2002;112(3 Pt 1): 1112-32. 